\title{
The Language Learning Benefits of Extensive Reading:
}

\section{Teachers Should Be Good Role Models}

\author{
Gopala Krishnan \\ Language Department, UiTM Cawangan Terengganu Kampus Dungun \\ Tel: 60-12-900-2602 E-mail: gopal792@tganu.uitm.edu.my \\ Rozlan Abdul Rahim \\ Language Department, UiTM Cawangan Terengganu Kampus Dungun \\ Tel: 60-13-932-1260 E-mail: rozlanab@tganu.uitm.edu.my \\ Rasaya Marimuthu \\ Language Department, UiTM Cawangan Terengganu Kampus Dungun \\ Tel: 60-12-989-2270 E-mail: rasay386@ppinang.uitm.edu.my \\ Rahman Bin Abdullah
}

Faculty of Hotel and Tourism Management, Universiti Teknologi MARA

Dungun, 23000, Terengganu Malaysia

Tel: 60-19-741-6820Ｅ-mail: rahma255@tganu.uitm.edu.my

Faizah Mohamad

Language Department, UiTM Cawangan Terengganu Kampus Dungun

Tel: 60-12-989-2270Ｅ-mail: fareema@tganu.uitm.edu.my

Kamaruzaman Jusoff (Corresponding author)

TropAIR, Faculty of Forestry, Universiti Putra Malaysia, 43400 Serdang, Selangor. Malaysia

Tel: 60-19-227-9507Ｅ-mail: kjusoff@yahoo.com

\begin{abstract}
Visioning a world class university is certainly an appropriate target for a university. Realizing this vision would need an expansion of knowledge and greater English proficiency as in this period of history, English is the language of IT which is an important key to acquiring knowledge. Using a sample of 40 level one students from UiTM Dungun this study found that in tandem with studies done elsewhere, extensive reading does seem to make a difference in the proficiency level of the students. Further the study also found that students who have a positive predisposition towards English read more and achieved better grades. However the study found no difference in the amount of reading done by boys and girls. The study discussed qualitatively the ability of teachers to inculcate the reading interest in the students, thus it is a triangular study which employs quantitative and qualitative means.
\end{abstract}

Keywords: Attitude, Language proficiency, Extensive reading, Reinforcing structures, Teacher quality

\section{Introduction}

It is a fact that in this globalized era of the new millennium English has evolved into a more vital international language than it was before. The use of English in IT has made it imperative for non-English populations even in those countries such as France, Germany and China to become literate in English. This study accepts the government's wisdom that English proficiency is a necessity for Malaysians. As such, this study would not address the issue of whether English is as vital as we are made to believe. Having accepted the importance of English to the nation as being a settled fact, this study explores whether reading materials in English, on a regular and consistent basis and in sufficient quantity, makes a difference in the English Language proficiency of the students.

There is little doubt that students coming out from our universities are facing English Language proficiency problems. According to government sources, this has affected their job prospects (The New Straits Times, July 18, 2003). The government has responded to this situation by giving English Language courses to jobless graduates of local universities. These classes which began in 2002 and go by the Bahasa Malaysia acronym of SSL was aimed towards improving the English Language proficiency of the students. In late 2002, the government spent more than RM 100 million to give retraining in the English Language to some 15,000 graduates. The government is planning to spend the 
same amount in 2003 for the same purpose. It is ironical that universities which exist to equip students with the necessary skills should fail in the task where English is concerned, making it necessary for post university training. Yet the problem did not start at the university. The school system had fed the university with students of questionable English proficiency. So universities, instead of involving students in intellectual discourse during English lessons continue the schools roles of teaching proficiency in the same ineffective manner of workbook work and exercises. This results in many students leaving the university with the English proficiency problems unresolved.

This state of affairs raises serious questions as to why our university graduates fail to acquire the necessary English Language skills after a lengthy period of studying English. A possible factor may be the students' lack of exposure to real life English. The students are exposed to workbook exercises and other forms of exercises in the classrooms. But this is not reinforced by subsequent exposure to real life English. Foreign maids with hardly any education or knowledge of English seem to be picking up a working knowledge of it merely by being exposed to the English language environment of their place of work which may be the home of a professionally qualified couple. Elley (1991) carried out some studies referred to as the 'Book Flood' studies. These studies showed marked improvements in second language acquisition. He gave five reasons why reading extensively results in improvement in proficiency. According to him, extensive reading involves extensive input of meaningful prints giving rise to substantial incidental language input. Elley found that the reader focuses more on meaning rather than on form, thus coming to acquire a high intrinsic motivation if the content interests him. Nation (1997) also found reading to be effective in enhancing second language proficiency. He found that as reading is an individual activity, learners of different proficiency levels can progress at their own pace. Additionally, Nation saw that reading gives the learner the freedom to choose the content area of the reading, this he says plays an important part in maintaining the interest of the learner. Nation stresses that reading outside the classroom allows for language input outside the classroom and this he says effectively reinforces and internalizes structures which may have been learned in the classroom. Without such reinforcement, he feels that whatever learning that has taken place in the classroom would atrophy due to lack of use. He finds that classroom lessons are not tailored to individual levels. Besides being inflexible, the lessons may be boring and may be dealing with content areas not within the learner's scope of interest. Under such circumstances, he feels that credible language acquisition may not occur.

Saragi et al. (1978) have also carried out research on the merits of reading in acquiring second language. They found that extensive reading results in a substantial increase in the vocabulary of the learner which is acquired by grasping the meanings of words in context. They stress that extensive reading is vital for increasing learners' repertoire of vocabulary in context, which cannot be acquired even by referring to the dictionary. Classroom activities do not offer a wide enough scope for the acquiring of vocabulary in context. They feel that unless the learner is immersed in an English speaking environment, he has to read extensively to acquire a usable level of vocabulary in context. Hamp-Lyons (1985) in her studies found remarkable increases in language acquisitions through extensive reading especially when English is a second language. She reported findings that showed that readers become interested in the language because of the reading they do. Readers begin to view language as capable of generating interesting meaning to them, this motivates them to continue reading and the exposure therein achieved serves to fortify and internalize correct structures and meanings. Laufer-Dvorkin (1981) found substantial increase in a learner's vocabulary and discourse generating abilities through extensive reading. He found that syntax becomes internalized through extensive reading. The pattern of the English language appears to become ingrained in the minds of the readers. Thereby they continue producing syntax which conforms to these patterns. Extensive reading imbibes in the readers a wide store of vocabulary. The familiarity of syntactic patterns acquired through extensive reading enables the learners to string together various words to produce their own creative original language which is in conformity to established patterns.

The above by no means exhausts the corpus of data available about the language learning benefits of extensive reading, however the constraints of this brief study does not make it possible to mention more of the available literature. This study will not only focus on the language learning benefits of extensive reading but will also question the teacher's ability to get students to be interested in reading. Ground breaking discoveries that research may uncover leading to more novel programmes by the Ministry will be of no avail if those destinies are to implement these programmes falter in their tasks. The majority of our students do not have an opportunity for such an exposure. They cannot create such an environment. However, it is possible for them to create their own reading environment. Reading is also an exposure to English in its real life form. This study explores whether there is a relationship between the amount of reading and English Language proficiency. This study was designed to seek answers for each of these questions, namely (a) do students who read more English Language materials (outside their course content) possess greater English Language proficiency? (b) does a positive attitude towards the English Language induce students to read more materials in the English Language? And (c) do girls generally read more English Language materials than boys?

\section{Methodology}

\subsection{Framework and definitions}

The theoretical framework model depicted (Figure 1) is a derivation of the model used by Spolsky (1989). He explores the influences of attitude and other social factors on language learning. The gender factor indicated in the model is 
derived from Spolsky's more global social factors. As the model shows, English Language proficiency will be the ultimate dependent variable whereas the quantity of English Language reading done will be an independent variable in reference to the English Language proficiency. However, both gender and attitude will serve as independent variables to the quantity of English Language reading done. In effect, the quantity of reading done will function as a dependent variable with regards to attitude and gender.

In this study, the achievement indicator which is the dependent variable will be the BEL 100 English grade of the students in the first semester of the 2003/4 academic year. This grade is deemed by the researcher as a legitimate yardstick of the students' English Language proficiency as it tests the students' skills of speaking, comprehension, writing and inferencing. The gender of the students will be either male are female. The quantity of English Language material reading done refers to the amount of the print in English that the student has read outside of his course books of the subject of his specialization. This would include the amount of time the student spends reading newspapers, magazines, books (fiction and non-fiction)) and internet browsing. The amount of time spent by the student in the reading of the above on a daily, weekly, monthly and yearly basis will be accepted as a quantifiable measure of the amount of reading that he/she has done. Meanwhile, the attitude as defined by Deci and Ryan (1985) refers to the state of the mind that determines the behavioural reactions towards external stimulus.

\subsection{Population and sample}

According to Gardner (1974), a population is a group of individuals who share at least one common characteristic. In this study, the common characteristic is that all of them are first year semester one students of UITM Dungun. This then will comprise the population. Out of this, will be taken a sample of 40 students from whom the information needed for this research will be obtained.

\subsection{Instruments}

The instrument used contained three material sections, namely Sections A, B and C. Section A was aimed at finding out the amount of reading that the students have done in English. This part of the questionnaire will elicit information about the students' reading habits. The questionnaire used will be a derivative of the one used by Gan (1999). The scores from Section A will enable the researcher to answer the first research question. The score for Section A will be obtained mainly by finding out the amount of time that a student uses to read non-course related materials in English. The time used daily, weekly, monthly and yearly will be obtained to assign a numerical value to the amount of reading done. Menwhile, Section B of the questionnaire would investigate the students' attitude towards reading materials in English. This section will adopt Gan's (1999) derivative of Gardner and Lambert's (1972) attitude/motivation test battery. Gan used her derivation for her study on the relationship between home environment, motivational intensity, desire to learn English and the importance of learning English.

Section $\mathrm{C}$ is to determine the descriptive statistics of the students' sex. It will be a two-item section, one to indicate the respondent's sex and the other, his/her achievement grade.

\section{Results and discussion}

The t-test below showed that there is no significant difference in the amount of reading done by boys and girls. The instrument shows reliability with a Cronbach's Alpha of 0.568 and 0.512 as shown in the table above. The Amount of Reading 7 would be the highest reading score while 35 would be the smallest count. The sample had a mean of 23.72 (Table 11). Meanwhile, the Attitude Level as indicated in Table 12 has a sample mean attitude score of 25.8. The score which would indicate the most positive attitude will be 10 while 50 would be the least positive score. On the other hand the best Achievement possible is grade $\mathrm{A}$ and is given a numerical equivalent of 1 . The lowest achievement is $\mathrm{E}$ which is given the numerical value of 5 . The mean for achievement is 2.45 which is between grades B and C (Table 11). It is quite evident that there is no significant difference between the male and female respondents for the amount of reading done (Table 13).

The results showed that students who read more in English as determined by their score for Section A have greater English language proficiency. The results of the score generally indicated that reading materials outside the classroom subject areas do help in the proficiency level of the respondents. This is in line with Bell's (1988) findings that extensive reading increases the exposure level of the learner to the language, thereby enhancing the learner's general language competence. A learner cannot learn English in a vacuum, there has to be exposure to real world English either in the form of the spoken word or the written text. Malaysian school students have wide exposure to workbook exercises. Workbook exercises do not necessarily duplicate real world communication in the form of speech or writing. Workbook exercises may have a place if they are supplemented by exposure to real world English communication. In the Malaysian scenario, students have very wide exposure to filling in the blanks and doing grammar exercises in workbooks, all of which come to naught when they are not internalized by real world experience. This would explain why after years of learning English the student finds that he cannot adequately communicate in English either in the oral or written form although he may have a fair understanding of both the oral and written forms. 
In the Malaysian context, a student has very little exposure to the oral form of English. Mostly he does not hear English being spoken in his school or home environment except for a minority who speak English at home. Even those who speak English at home do not really have lengthy discourses as children do not talk a great deal to their parents. This means that the only form of exposure to real world English available to the student will be the printed form. Elley and Mangubhai (1983) found that a group of Fijian children improved their English language proficiency at twice the normal rate, in their "Book Flood" study. Subsequently, Elley (1991) showed striking increases in measures of language use, by students involved in his "Book Flood" studies. The "Book Flood" study involved learners spending the greater part of their class time reading books that interested them. Being aware of the vital role that general reading can play on attaining language proficiency, the Malaysian Ministry of Education had on various instances tried to generate the reading habit among Malaysian students. The period from the mid to the late 80 s saw the introduction of The English Language Reading Programme (ELRP) to lower secondary students. The personal observation of the researchers was that many of these books which were produced at great costs, remained in their boxes in mint conditions due to lack of use. Seeing the futility of giving schools a programme which they can use at their own option, the Ministry reintroduced Class Readers into the English Language teaching scenario and the schools were told to use 20 percent of the weekly English Language teaching time of a class for these Readers. These Readers were also produced at great cost and many of them dealt with local folklores such as "Pak Belalang" and "Malim Nawar" in the hope that familiar content would attract students towards reading the books. Elaborate teaching guides called "Files" were prepared for each book to assist teachers in using the Class Readers. The Class Readers project appears to have suffered the same fate as the ELRP. The CDC in the mid 80s also came up with a programme acronymed "DEAR" (Drop Everything and Read). This programme too did not get off the ground. Also in force is a programme named the 'Nilam' project which is aimed at getting students to read? Realising that neither schools nor students would do anything unless instrumentally motivated; the Ministry finally introduced English Literature in 1998 and made it a compulsory component of both the school and national level examinations.

All the ministerial effort towards getting students to read shows that they are sold on the theory of acquiring proficiency through reading. Going by the present English Language scenario, it appears that the Ministry has not failed to plan, just that its plans may have failed to work. The plans are conceptually sound and in line with the corpus of data available on researches about reading. This raises the inevitable question, why did a well-founded plan fail to work? Future researches have to address the question of the school teachers' efforts of getting students to love reading. Whatever the merit of the plans introduced by the ministry, its implementation and by extension its success and failure depends on those on the field, namely the school teachers, whose duty it is to carry out the plans introduced by the ministry. It is now five years since the introduction of the compulsory English Literature programme. Some of the students involved in the programme have already come into the job market. According to newsreports the English Language scenario is as depressing as before. Now that the reading component is a compulsory part of the English curriculum, would the standard of English show an appreciable improvement, given time? If the earlier programmes did not produce the desired results because the English Language practitioners did not zealously promote reading among students as is intended by the letter and spirit of the ministerial plans, would they be successful now with the same practitioners entrusted to implement it, now that it is made compulsory? If the teachers are not converted to the idea of reading as a vital means of improving proficiency, would they be able to get students to be interested in reading just because it is a compulsory component? Is it possible that the English literature book would be treated as a lengthy comprehension exercise meant for passing examinations? If the answers to all these questions are in the affirmative, then very little improvement through reading can be expected as students may not be converted into lovers of reading. If the English literature component is made into a workbook form rather than a piece of interesting prose to be appreciated for its story content, then it is questionable whether the teachers will be able to take advantage of English literature to build up a love for reading amongst the students.

While this study and others before it show the positive proficiency achievement results arising out of reading for leisure, it is prudent to be cautious about the benefits that we can reap from introducing English literature as a compulsory component. If the teachers were to deal with it from a purely an examination perspective, then, the intended aim of getting students to continue reading English Language materials on their own momentum may not materialize. In the face of many sound plans which have failed to produce desired effect, it may not be untimely for the Ministry to focus its attention on those whose duty it is to implement their plans, namely the school teachers. "The frontline soldiers must believe in the cause that they are fighting for." The Ministry must convert the "plan executors" before they can convert others. Relevant courses for existing teachers of English must be held to get them to realize the importance of reading and to get them to be readers themselves. The teacher training scenario for English teachers has also to be looked into to produce English teachers who are readers and who would zealously encourage their students to read. This is in line with one of Day and Bamford's (2002) 10 principles of extensive reading which postulates that teachers themselves have to be ardent readers for the success of extensive reading among students. At this juncture, it might not be irrelevant to suggest that the quality of the English teachers be improved, new English teachers joining the profession should be 
required to sit for the MUET examination and obtain at least Band 5 before they are considered for confirmation. Teachers who have a certain level of English proficiency would more easily be converted to the cause and be more effective implementers of the spirit of the plans laid out by the Ministry.

This study also found out that students with a positive attitude generally read more than students who did not. These students also showed better English proficiency scores. There is already in existence a formidable corpus of data which indicate that attitude and motivation are crucial in producing greater English Language achievement. Therefore where schools are concerned teachers must ensure that students are at all times highly motivated. However going by the frequent laments of teachers that the students are uninterested in learning the language, it can be seen that teachers are unable to sustain or inculcate in students the interest towards learning English. Students may get interested due to the emphasis placed on English by the government and society. However, this will not produce the desired outcome if teachers fail to nurture and sustain their interest. Scarcella and Oxford (1992) as cited in a study done by Kardina and Ridwan (2002) which was presented at the 2002 Academic Conference of UITM Dungun, state that attitude and motivation in most cases, will serve to enhance the learning of L2. Kardina and Ridwan (2002) further stated that: 'This study has shown that the participants are not at all 'unmotivated' and do not have very poor attitudes towards learning ESL. This is clearly something for the teachers to take opportunity of. With such positive attitudes and considerably strong motivation, we believe any carefully thought-out effort made to improve the students' learning will be fruitful.' This underscores the contention of this study that students by virtue of their very nature of being young human beings come into class with expectation, curiosity and interest. In spite of this, English proficiency has indisputably remained at a lamentable state. Hence, this study further stresses that it is imperative that the Ministry does not just focus on bringing new approaches to students but also reflect seriously on how effectively the executors would carry out the plans. Teachers often lament that the dismal state of English is due to the students' lack of interest. That time has come when teachers have to view the students' lack of interest as their own failure to interest the students. It is not an extreme view to state that not only could teachers have failed to arouse the interest of the students, they could also dampened whatever interest and eagerness that the students might have had at the beginning. Unimaginative teaching methods used by the teacher who lacks personality may have a lot to do with killing the interest with which the students might have started their study of English at the onset.

Many teachers also feel that the Ministry is partially to be blamed for the dismal state of English as the Ministry has not decided to make a pass in English compulsory. These teachers feel that legislation would succeed where teaching methods fail. In a non-academic vein, these researchers might add that what is good for the goose is also good for the gander. If by the reckoning of the teachers legislation can work for the students, it should be equally effective in ensuring teacher quality, commitment and motivation. As suggested earlier, a step in this direction could start by making it necessary for all English teachers who do not have an A for the English proficiency papers at the university level to sit for the MUET paper and obtain a band of at least 5. This would ensure that teachers whose English is suspect would redouble efforts to improve their English. Such efforts would include general reading in English. Better quality English teachers who are themselves readers would be better placed to improve the English of the students and get students to increase exposure time to English by reading in English for leisure. These better quality teachers would also be better implementers of the programmes of the Ministry which are generally in tandem which language teaching development all over the globe. If the issue of the instructors of English is not addressed, then the best laid plans would meet an all too familiar fate. Many teachers view the teaching of English as the incessant feeling up of workbooks and leaving no blanks unfilled. The literature component recently introduced by the Ministry is already suffering a similar fate. Teachers should be trained to exploit literature to get students to be interested in reading English materials as a source of entertainment.

In another part of their study, Kardina and Ridwan (2002) had this to say: 'In the absence of a clear relationship between attitude, motivation, and language competence, what can we comment on the much-lamented poor standard of English among our students? Common sense tells us we should begin looking in other directions. Although attitude and motivation are recognized to be important in L2 learning, they are not known to be the only factors.' This study postulates that one of the important "other factors" that they had intimated should be the teacher factor. Their study also had this to say about the instructors: "To explain the poor level of English among school students and what can be done where the classroom is concerned, we believe it is useful to reflect on what the teachers usually do. It may be possible to improve the learning of these students by first improving what and how teachers teach. Research often indicates that a sound methodology is one that is dynamic, continually taking into account the various elements present in the teaching-learning environment (Brown, 1987)" Given that these elements are many and diverse, teachers need to be prepared to effect changes. In the light of this it is imperative that the teacher training of new batches of English teachers be reflectively looked into and in the case of existing teachers, in service courses could be held to re-orientate them. Going by their own reasoning about making a pass in English compulsory, even the best training methods would not work unless aided by legislation, in line with this it should be made compulsory for teachers of English to obtain at least a Band 5 score in MUET. In the early 70s, many teachers were weak in Bahasa Malaysia thereby appearing to 
jeopardize the government's plan of having Bahasa Malaysia as a medium of instruction. To redress this, a credit in Bahasa Malaysia was made mandatory for teacher confirmation. True to form Bahasa Malaysia proficiency problems faced by the teachers evaporated and the Ministry was able to successfully switch to Bahasa Malaysia as the medium of instruction. If this method worked for Bahasa Malaysia, it would certainly work for English too, making it compulsory for English teachers to get a Band 5 in MUET would get them to improve their English as much by reading as by any other available method. This then would result in a higher quality pool of English teachers and a higher level of proficiency among students can be expected when teachers start teaching with more confidence and commitment.

According to Hall (1964), “A teacher must elicit enthusiasm from his pupils by resonance from his own person”. As the quotation implies, teachers cannot blame students if students are not interested. It is no use merely pulling the proverbial horse to the water without first making the horse thirsty. The standard of the instructor's English has also been variously questioned by many sectors, including in the press. Hence, the mention of it in this study is no shocking revelation. Teachers who have not adequately mastered the language and do not read for leisure cannot be expected to generate students' interest in reading. In the Malaysian context, reading is very important to students as this is the only means by which they can get exposure to reinforce and internalize whatever grammar and structures that they learnt in class. A Malaysian school student may generally be deaf to English as his only audio input of English may be the few words that he listens to, in the classroom. If additionally he does not read in English then he becomes not only deaf but blind to the language. Given these circumstances, it is no mystery why a student can leave university after many years of studying English and yet is only capable of producing flawed and defective speech and writing. The teacher must be a reader first before getting the students to be interested in reading. When Bahasa Malaysia was made compulsory for teachers in early 70s, many of them started reading Bahasa Malaysia materials such as the Utusan Malaysia newspaper and the Dewan Masyarakat magazine. Requiring them to get a Band 5 in MUET would produce the same results, they would read to improve and given the wealth of fiction and non fiction reading materials in English, these teachers may continue to be readers out of their own interest and not because they are forced to. This will also enable them to increase their intellectual development. Such teachers then would be better equipped to get students to start reading and increase their exposure time to English, thereby improving their English proficiency. The students are not in control of his environment and as such merely insisting that he practise his English Language in order to improve, is impractical advice. However the students is in complete control of how much he reads for which reason he has to practise his English by reading English materials and reap the benefits that Elley (1991) spoke of.

Another interesting point to note is that there was no difference in the amount of reading done by the girls and boys. Also there was no significant difference in their English Language achievement. The researchers also orally interviewed the girls and boys in the sample. The oral interview uncovered that the girls generally read more than the boys as they had fewer options when it comes to spending leisure time. However the girls mentioned that most of their leisure time reading was done in Bahasa Malaysia. Hence, the reading record of the girls in English Language was nearly the same as the boys.

\section{Conclusion}

To conclude, we would like to restate the findings of the research namely, that for a student to excel in any language, exposure time to that language has to be chalked up. In the Malaysian context the best form of exposure is reading. This is so because the student is not immersed in an English speaking environment. He is in no control of his environment. However he can be made to be in control of his reading. If he is made to love reading the dismal state of English in our country may be reversed. Reading is a form of real world communication. A positive attitude towards reading materials in English causes a student to read more and reap its inherent benefits. However the teachers must themselves be converted to this cause before they can be expected to get students to be interested in reading English Language materials, otherwise the best of plans by the Ministry would continue producing the same lack of results as have all the past programmes. Requiring English teachers to obtain a Band 5 in MUET may seem shocking and draconian but it may be the necessary step that might be able to shock the teachers out of their reverie and produce the desired results.

The researchers have over the course of the years interviewed many students who have good English proficiency. Invariably these students come from the homes of educated parents and these students have the habit of reading materials in English. In other words, they did not acquire their proficiency through the school system but it was their home situation that enabled them to have the proficiency that they possess. Thus the school appears to have been ineffectual in producing students with good English Language proficiency primarily because they did not succeed in getting students to be interested in reading. It is the observation of the researchers that many students of the $50 \mathrm{~s}$ and $60 \mathrm{~s}$ from labour class homes possessed credible English Language proficiency not only because they came from English medium schools but also because they read a lot in English at a time when other forms of entertainment may be lacking. The Education Ministry's plans are conceptually sound but it should not overlook the human element involved in implementing the plans. The last research question dealt with the issue of gender and reading but as far as the sample taken goes, the two genders did not show a significant difference in the amount of reading done in English. 


\section{References}

Bamford, J. \& Day, R. (2002). Top ten principles for teaching extensive reading. Reading in a Foreign Language, 14(2).

Bell, T. (1998). Extensive reading: Why? And how?. The Internet TESL Journal, 4(2). Retrieved July 1, 2003, from http://iteslj.org/Articles/Bell-Reading.html.

Challenging Times for Graduates (2003, July 18). The New Straits Times, 5.

Deci, E. L., \& Ryan, R. M. (1985). Intrinsic motivation and self-determination in human behaviour. New York: Plenum Press.

Elley, W. B. (1991). Acquiring literacy in a second language: The effect of book-based programs. Language Learning, 41(3), 375-411.

Elley, W. B., \& Mangubhai, F. (1983). The effect of reading on secoind language learning, Reading Research Quarterly, 19(1), 53-67.

Gan, A. G. (1999). Home environment/motivation factors associated with English language achievement of form four Malay students in a rural secondary school in Penang. Unpublished M. Ed. practicum report, USM.

Gardner, R. C. (1974). Effects of attitudes and motivation on student stereotypes. Alberta Journal of Educational Research, 20, 270-277.

Gardner, R. C. \& Lambert, W. E. (1972). Attitudes and motivation in second language learning. Massachusetts: Newbury House Publishers.

Hamp-Lyons, E. (1985). Two approaches to teaching reading: A classroom-based study. Reading in a Foreign Language, 3(1), 363-73.

Hall, J. (1964). Teacher Education. Camridge: Cambridge University Press.

Laufer-Dvorkin, B. (1981). "Intensive" versus "extensive" reading for improving university students' comprehension in English as a foreign language. Journal of Reading, 25(1), 4043.

Mohd. Ridwan Abdul Wahid \& Kardina Kamaruddin. (2002). 'Attitudinal and motivational factors in the learning of English at UITM Cawangan Terengganu', In the Konferensi Akademik UiTM Cawangan Terengganu Kampus Dungun 2002, Kelantan 23-25 October, 2002.

Nation, P. (2003). 'The language learning benefits of extensive reading.' Retrieved July 9, from http://langue.hyper.chubu.ac.jp/jaltpub/tlt/97/may/extensive.html.

Saragi, T., Nation, I. S. P. \& Meister, G. F. (1978). Vocabulary learning and reading. System, 6(2), 72-78.

Spolsky, B. (1989). Conditions for second language learning. Oxford: Oxford University Press.

Table 1. Demographic Profile of Participants

\begin{tabular}{lll}
\hline Demographic Factors & Frequency & Percentage (\%) \\
\hline Gender & & \\
Male & 18 & 45.0 \\
Female & 22 & 55.0 \\
Total & 40 & 100.0 \\
\hline
\end{tabular}

Table 2. Distribution of Items in The Questionnaire

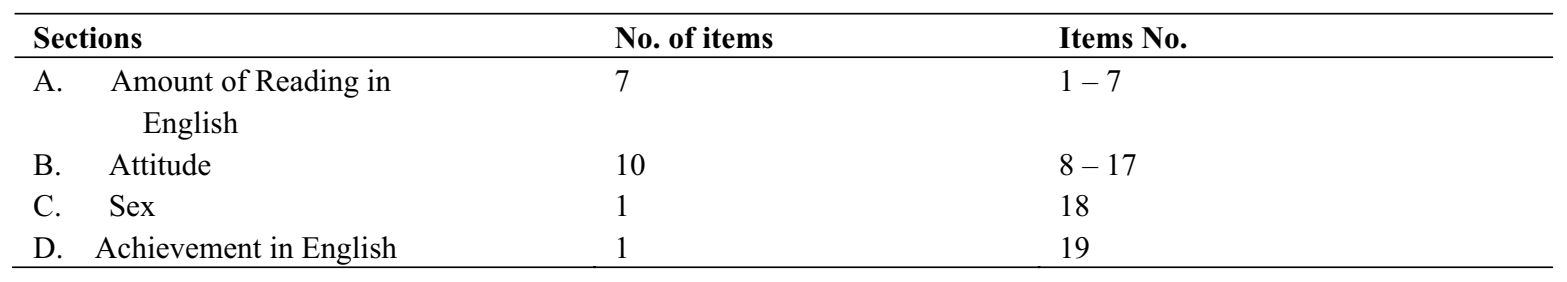


Table 3. Reliability Coefficient of The Study Variables Using Cronbach's Alpha

\begin{tabular}{lll}
\hline Group Item & No. of Items & $\begin{array}{l}\text { Cronbach's Alpha } \\
\mathbf{n = 4 0}\end{array}$ \\
\hline Amount of Reading in English & 7 & .568 \\
Attitude & 10 & .512 \\
\hline
\end{tabular}

Note: Cronbach's Alpha $0.8-1.00 \quad$ (very strong reliability)

$$
\begin{array}{ll}
0.7-0.79 & \text { (strong reliability) } \\
0.5-0.69 & \text { (reliable) } \\
0.3-0.49 & \text { (moderately reliable) }
\end{array}
$$

Table 4. Average Time Spent Reading English Newspapers In A Day (N=40)

\begin{tabular}{lllll}
\hline & Frequency & Percent & Valid Percent & $\begin{array}{l}\text { Cumulative } \\
\text { Percent }\end{array}$ \\
\hline$>$ than 30 minutes & 5 & 12.5 & 12.5 & 12.5 \\
$20-30$ minutes & 1 & 2.5 & 2.5 & 15.0 \\
$10-20$ minutes & 1 & 2.5 & 2.5 & 17.5 \\
$1-10$ minutes & 13 & 32.5 & 32.5 & 50.0 \\
0 minutes & 20 & 50.0 & 50.0 & 100.0 \\
\hline Total & 40 & 100.0 & 100.0 & \\
\hline
\end{tabular}

Table 5. Average Time Spent Reading English Newspapers In A Week $(\mathrm{N}=40)$

\begin{tabular}{lllll}
\hline & Frequency & Percent & Valid Percent & $\begin{array}{l}\text { Cumulative } \\
\text { Percent }\end{array}$ \\
\hline$>$ than 30 minutes & 14 & 35.0 & 35.0 & 35.0 \\
$20-30$ minutes & 2 & 5.0 & 5.0 & 40.0 \\
$10-20$ minutes & 4 & 10.0 & 10.0 & 50.0 \\
$1-10$ minutes & 9 & 22.5 & 22.5 & 72.5 \\
0 minutes & 11 & 27.5 & 27.5 & 100.0 \\
\hline \multicolumn{1}{c}{ Total } & 40 & 100.0 & 100.0 & \\
\hline
\end{tabular}

Table 6. Average Time Spent Reading Magazines in a Week $(\mathrm{N}=40)$

\begin{tabular}{lllll}
\hline & Frequency & Percent & Valid Percent & $\begin{array}{l}\text { Cumulative } \\
\text { Percent }\end{array}$ \\
\hline$>$ than 60 minutes & 10 & 25.0 & 25.0 & 25.0 \\
$30-60$ minutes & 0 & 0.0 & 0.0 & 25.0 \\
$15-30$ minutes & 2 & 5.0 & 5.0 & 30.0 \\
$1-15$ minutes & 5 & 12.5 & 12.5 & 42.5 \\
0 minutes & 23 & 57.5 & 57.5 & 100.0 \\
\hline \multicolumn{1}{c}{ Total } & 40 & 100.0 & 100.0 & \\
\hline
\end{tabular}

Table 7. Average Time Spent Reading Magazines in a Month $(\mathrm{N}=40)$

\begin{tabular}{lllll}
\hline & Frequency & Percent & Valid Percent & $\begin{array}{l}\text { Cumulative } \\
\text { Percent }\end{array}$ \\
\hline$>$ than 60 minutes & 17 & 42.5 & 42.5 & 42.5 \\
$30-60$ minutes & 2 & 5.0 & 5.0 & 47.5 \\
$15-30$ minutes & 0 & 0.0 & 0.0 & 47.5 \\
$1-15$ minutes & 6 & 15.0 & 15.0 & 62.5 \\
0 minutes & 15 & 37.5 & 37.5 & 100.0 \\
\hline \multicolumn{1}{c}{ Total } & 40 & 100.0 & 100.0 & \\
\hline
\end{tabular}


Table 8. Average Time Spent Browsing the Internet Reading Non-course Related Materials (in English) in a Week $(\mathrm{N}=40)$

\begin{tabular}{lllll}
\hline & Frequency & Percent & Valid Percent & $\begin{array}{l}\text { Cumulative } \\
\text { Percent }\end{array}$ \\
\hline$>$ than 60 minutes & 16 & 40.0 & 40.0 & 40.0 \\
$30-60$ minutes & 0 & 0.0 & 0.0 & 40.0 \\
$15-30$ minutes & 4 & 10.0 & 10.0 & 50.0 \\
$1-15$ minutes & 9 & 22.5 & 22.5 & 72.5 \\
0 minutes & 11 & 27.5 & 27.5 & 100.0 \\
\hline \multicolumn{1}{c}{ Total } & 40 & 100.0 & 100.0 & \\
\hline
\end{tabular}

Table 9. Average Time Spent Browsing the Internet Reading Non-course Related Materials (in English) in a Month $(\mathrm{N}=40)$

\begin{tabular}{lllll}
\hline & Frequency & Percent & Valid Percent & $\begin{array}{l}\text { Cumulative } \\
\text { Percent }\end{array}$ \\
\hline$>$ than 60 minutes & 16 & 40.0 & 40.0 & 40.0 \\
$30-60$ minutes & 0 & 0.0 & 0.0 & 40.0 \\
$15-30$ minutes & 6 & 15.0 & 15.0 & 55.0 \\
$1-15$ minutes & 12 & 30.0 & 30.0 & 85.0 \\
0 minutes & 6 & 15.0 & 15.0 & 100.0 \\
\hline \multicolumn{1}{c}{ Total } & 40 & 100.0 & 100.0 & \\
\hline
\end{tabular}

Table 10. Number of Fiction and Non-Fiction Books read in a Year $(\mathrm{N}=40)$

\begin{tabular}{lllll}
\hline & Frequency & Percent & Valid Percent & $\begin{array}{l}\text { Cumulative } \\
\text { Percent }\end{array}$ \\
\hline$>$ than 6 books & 6 & 15.0 & 15.0 & 15.0 \\
$5-6$ books & 0 & 0.0 & 0.0 & 15.0 \\
$3-4$ books & 0 & 0.0 & 0.0 & 15.0 \\
$1-2$ books & 12 & 30.0 & 30.0 & 45.0 \\
0 books & 22 & 55.0 & 55.0 & 100.0 \\
\hline \multicolumn{1}{c}{ Total } & 40 & 100.0 & 100.0 & \\
\hline
\end{tabular}

Summary of Descriptive Statistics

Table 11. Mean And Standard Deviation Of Variables Involved In The Study

\begin{tabular}{lllllll}
\hline Variables & $\mathbf{N}$ & Mean & $\begin{array}{l}\text { Standard } \\
\text { Deviation }\end{array}$ & $\begin{array}{l}\text { Minimum } \\
\text { Sample }\end{array}$ & $\begin{array}{l}\text { of } \\
\text { Maximum } \\
\text { Sample }\end{array}$ \\
\hline $\begin{array}{l}\text { Amount of } \\
\text { Reading in }\end{array}$ & & & & \\
English & 40 & 23.7250 & 5.9999 & 15.0 & 34.0 \\
Attitude & 40 & 25.8000 & 5.3790 & 10.0 & 34.0 \\
Achievement & 40 & 2.4500 & 1.2184 & 1.0 & 5.0 \\
\hline
\end{tabular}

Table 12. Analysis Of Correlation Between Variables (Pearson r)

\begin{tabular}{ccc}
\hline VARIABLES & ATTITUDE & GRADE \\
\hline READING HABIT & 0.130 & $0.587^{* *}$ \\
\hline
\end{tabular}

** Correlation is significant at 0.01 level (2-tailed)

* Correlation is significant at 0.02 level (2-tailed)

Note: $\quad r=1$

$\mathrm{r}=0.7-0.99$

(perfect correlation)

$\mathrm{r}=0.5-0.69$

(very strong correlation)

$\mathrm{r}=0.3-0.49$

(strong correlation)

$\mathrm{r}=0.1-0.29$

(moderate correlation)

$\mathrm{r}=0.01-0.09$

(weak correlation)

(very weak correlation) 
As shown in Table 12, there is a strong correlation $\left(\mathrm{r}=0.587^{* *}\right)$ between reading habit and grade. This is also a positive correlation $(r=0.130)$ between attitude and reading habit although it is a weak one.

Table 13. Independent Samples Test for Gender Differences for Amount of Reading

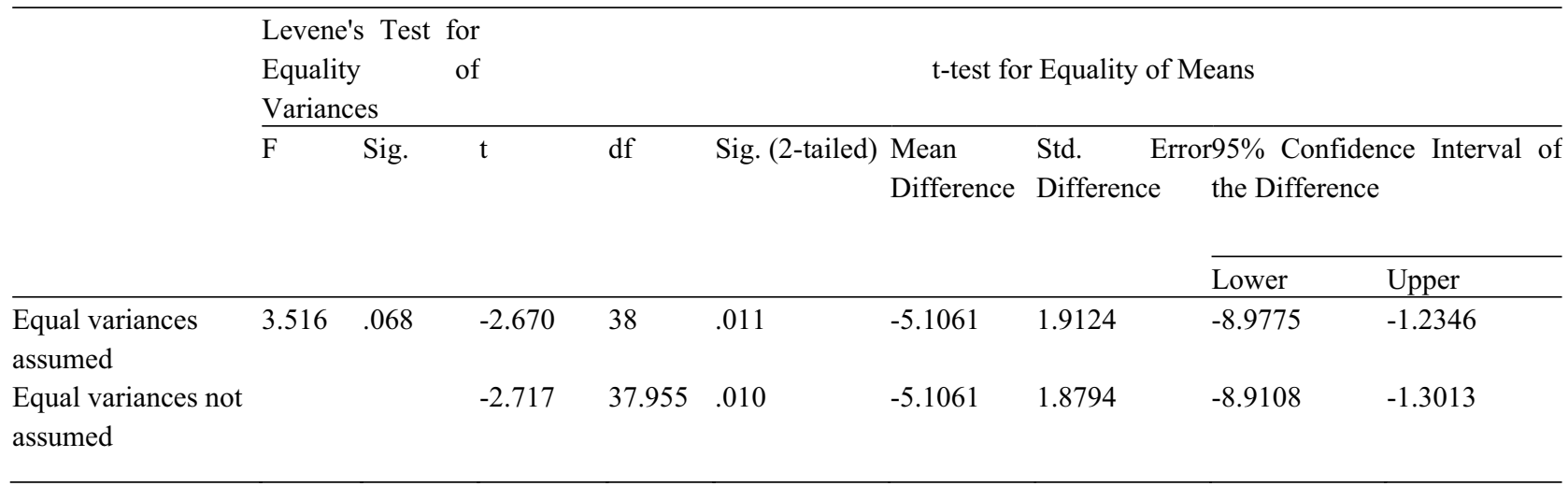

\section{INDEPENDENT VARIABLE}

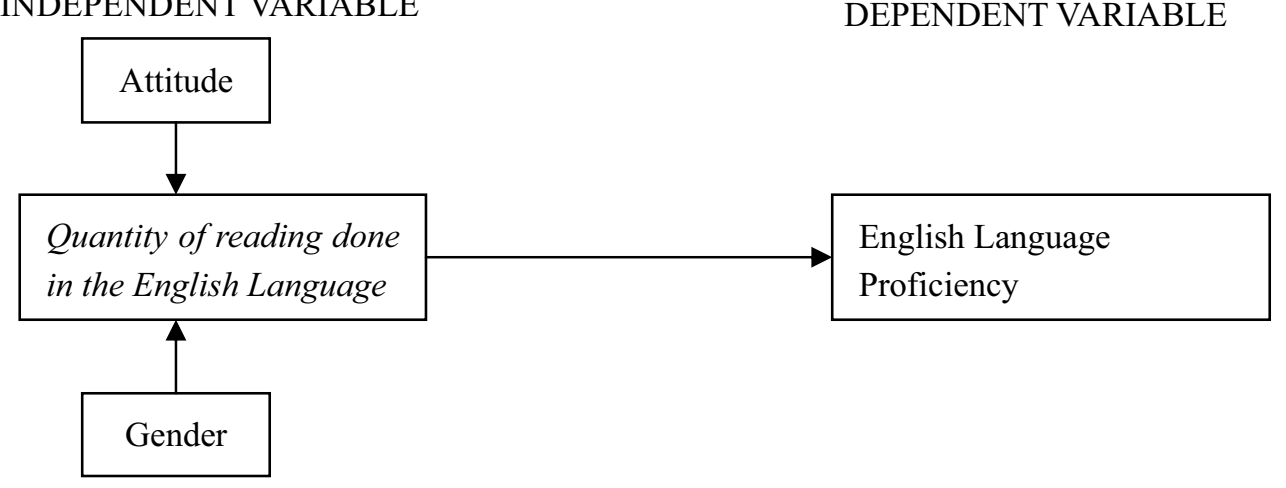

Figure 1. Research Framework: The relationship between the independent variable of quantity of reading (attitude \& gender) and the dependent variable of the students' English Language proficiency. 